\title{
Development of a novel radioligand for imaging 18-kD translocator protein (TSPO) in a rat model of Parkinson's disease
}

Chun-Yi Wu ${ }^{1,2}$, Yang-Yi Chen ${ }^{3}$, Jia-Jia Lin ${ }^{1}$, Jui-Ping Li ${ }^{4}$, Jen-Kun Chen ${ }^{4}$, Te-Chun Hsieh ${ }^{1,5^{*}}$ and Chia-Hung Kao ${ }^{5,6,7^{*}}$

\begin{abstract}
Purpose: The inflammation reaction in the brain may stimulate damage repair or possibly lead to secondary brain injury. It is often associated with activated microglia, which would overexpress $18-\mathrm{kDa}$ translocator protein (TSPO). In this study, we successfully developed a new TSPO radioligand, $\left[{ }^{18} \mathrm{~F}\right]-2$-(4-fluoro-2-(p-tolyloxy)phenyl)-1,2dihydroisoquinolin-3(4H)-one ( $\left.\left[{ }^{18} \mathrm{~F}\right] \mathrm{FTPQ}\right)$, and evaluate its potential to noninvasively detect brain changes in a rat model of Parkinson's disease (PD).

Procedures: The precursor (8) for $\left.{ }^{18} \mathrm{~F}\right] \mathrm{FTPQ}$ preparation was synthesized via six steps. Radiofluorination was carried out in the presence of a copper catalyst, and the crude product was purified by high-performance liquid chromatography (HPLC) to give the desired $\left[{ }^{18} \mathrm{~F}\right] \mathrm{FTPQ}$. The rat model of PD was established by the injection of 6-OHDA into the right hemisphere of male 8-week-old Sprague-Dawley rats. MicroPET/CT imaging and immunohistochemistry $(\mathrm{IHC})$ were performed to characterize the biological properties of $\left[{ }^{18} \mathrm{~F}\right] \mathrm{FTPQ}$.
\end{abstract}

Results: The overall chemical yield for the precursor (8) was around 14\% after multi-step synthesis. The radiofluorination efficiency of $\left[{ }^{18} \mathrm{~F}\right] \mathrm{FTPQ}$ was $60 \pm 5 \%$. After HPLC purification, the radiochemical purity was higher than $98 \%$. The overall radiochemical yield was approximately 19\%. The microPET/CT images demonstrated apparent striatum accumulation in the brains of PD rats at the first 30 min after intravenous injection of $\left[{ }^{18} \mathrm{~F}\right] \mathrm{FTPQ}$. Besides, longitudinal imaging found the uptake of $\left[{ }^{18} \mathrm{~F}\right] \mathrm{FTPQ}$ in the brain may reflect the severity of PD. The radioactivity accumulated in the ipsilateral hemisphere of PD rats at 1,2 , and 3 weeks after $6-\mathrm{OHDA}$ administration was $1.84 \pm 0.26,3.43 \pm 0.45$, and $5.58 \pm 0.72 \% \mathrm{ID} / \mathrm{mL}$, respectively. $\mathrm{IHC}$ revealed that an accumulation of microglia/macrophages and astrocytes in the 6-OHDA-injected hemisphere.

Conclusions: In this study, we have successfully synthesized $\left[{ }^{18} \mathrm{~F}\right] \mathrm{FTPQ}$ with acceptable radiochemical yield and demonstrated the feasibility of $\left[{ }^{18} \mathrm{~F}\right] \mathrm{FTPQ}$ as a TSPO radioligand for the noninvasive monitoring the disease progression of PD.

Keywords: Parkinson's disease (PD), 18-kD translocator protein (TSPO), $\left[{ }^{18} \mathrm{~F}\right] \mathrm{FTPQ}$, Positon emission tomography (PET)

\footnotetext{
*Correspondence: rancholosamigos@mail.cmuh.org.tw;

rancholosamigos@yahoo.com.tw; d10040@mail.cmuh.org.tw

'Department of Biomedical Imaging and Radiological Science, China Medical

University, No.91, Hsueh-Shih Road, Taichung, Taiwan, 40402

${ }^{5}$ Graduate Institute of Biomedical Sciences and School of Medicine, College

of Medicine, China Medical University, No.91, Hsueh-Shih Road, Taichung,

Taiwan, 40402

Full list of author information is available at the end of the article
}

(c) The Author(s). 2019 Open Access This article is distributed under the terms of the Creative Commons Attribution 4.0 International License (http://creativecommons.org/licenses/by/4.0/), which permits unrestricted use, distribution, and reproduction in any medium, provided you give appropriate credit to the original author(s) and the source, provide a link to the Creative Commons license, and indicate if changes were made. The Creative Commons Public Domain Dedication waiver (http://creativecommons.org/publicdomain/zero/1.0/) applies to the data made available in this article, unless otherwise stated. 


\section{Background}

Parkinson's disease (PD) is a neurodegenerative disorder characterized by impaired dopamine or norepinephrine production, and by the formation of alpha-synuclein. As PD progresses, patients would gradually have difficulty in initiating movement and may have mental and memory problems. Although the real cause of PD remains poorly understood, it is regarded that chronic neuroinflammation plays a vital role for this disease, supported by evidence from activated microglia in the substantia nigra of postmortem brain samples $[1,2]$ and inflammatory cytokines [3].

Microglia, presenting throughout the central nervous system (CNS), act as the first line of immune defense against invading pathogens and potentially initiate subsequent tissue repair [4]. The activity of microglia in a healthy brain is only at a basal level, but it would be upregulated in response to various CNS damages. The 18-kD translocator protein (TSPO), a transmembrane protein, is previously identified as a peripheral benzodiazepine receptor (PBR), and located in the outer membrane of mitochondria of microglia and astrocytes [5]. TSPO is an essential component of the mitochondrial permeability transition pore (mPTP) and can affect mPTP opening or closure, which would lead to apoptotic death or cell protection. A significantly elevated expression of TSPO has been observed upon the transition of microglia from a normal condition to the activated stage [6]. The glial proliferation may be the reason for the upregulation of TSPO, which can possibly increase neurosteroid synthesis to provide protective activity at injury sites [7]. Moreover, several studies reported that TSPO ligands could serve as a neuroprotective agent in the animal model of neuroinflammation [8-10]. The precise mechanism remains to be fully understood.

$\left[{ }^{11} \mathrm{C}\right] \mathrm{PK} 11195$ was the first positron emission tomography (PET) radioligand used to noninvasively quantify the expression level of TSPO in animal models and in PD patients. However, the inconclusive findings were noticed when using $\left[{ }^{11} \mathrm{C}\right] \mathrm{PK} 11195$ PET to detect PD. Among these studies, some revealed the accumulation of $\left[{ }^{11} \mathrm{C}\right] \mathrm{PK} 11195$ was proportional to the activated expression of TSPO in the brains of PD patients [11, 12], but the others did not support this finding [13]. The low target-to-background ratio of $\left[{ }^{11} \mathrm{C}\right]$ PK11195 caused by low specific binding, high plasma protein binding percentage, and low brain-blood barrier (BBB) penetration ability, might be the explanation for this inconsistency. Besides, the short half-life of $\mathrm{C}-11$ also limits its wide clinical application.

Regarding that TSPO is an appropriate target for noninvasive imaging, a number of second-generation TSPO radioligands, including $\left[{ }^{11} \mathrm{C}\right] \mathrm{PBR} 28, \quad\left[{ }^{11} \mathrm{C}\right] \mathrm{DAA} 1106$, $\left[{ }^{18} \mathrm{~F}\right]$ DPA714, and $\left[{ }^{18} \mathrm{~F}\right]$ FEPPA, have been developed [14]. Varnas et al. reported that $\left[{ }^{11} \mathrm{C}\right] \mathrm{PBR} 28$ accumulation in the brain of PD patients did not correlate with dopaminergic pathology [15]. The inconclusive findings warrant further study to develop novel selective and high-affinity radioactive TSPO ligand for visualization of activated microglia in PD with PET. Based on the scaffold of Ro5-4864, Elkamhawy et al. found the derivatives of 2-(2-aryloxphenyl)-1,4-dihydroisoquinolin-3(2H)-ones are able to modulate the opening/closure of MPTP and suggested them as potential TSPO ligands [16]. To the best of our knowledge, there are no ligands in this class to be labeled with radioisotopes. As a consequence, we synthesized the radioactive surrogate of 2-(2-aryloxphenyl)-1, 4-dihydroisoquinolin-3(2H)-ones $\left(\left[{ }^{18} \mathrm{~F}\right] \mathrm{FTPQ}\right)$ and determine its feasibility as a TSPO radioligand for imaging PD in a rat model.

\section{Methods}

Preparation of the precursor of $\left[{ }^{18} \mathrm{~F}\right] \mathrm{FTPQ}$

Synthesis of isochroman-3-one (2)

The synthetic scheme of the precursor of $\left[{ }^{18} \mathrm{~F}\right] \mathrm{FTPQ}$ was shown in Fig. 1. In the first step, m-chloroperbenzoic acid $(3.92 \mathrm{~g}, 22.7 \mathrm{mmol})$ was added into a solution of 2indanone (1) $(2 \mathrm{~g}, 15.13 \mathrm{mmol})$ in $20 \mathrm{~mL}$ of dichloromethane. The reaction mixture was stirred at room temperature (r.t.) for $24 \mathrm{~h}$ and then the quenched with $10 \%$ aqueous sodium thiosulfate. The resulting mixture was poured into cold brine and extracted with dichloromethane. The organic layer was dried with magnesium sulfate and then evaporated to dryness to give a product (2). Yellow solid, yield: $90 \%,{ }^{1} \mathrm{H}$ NMR $\left(400 \mathrm{~Hz}, \mathrm{CDCl}_{3}\right)$ $\delta=3.70\left(2 \mathrm{H}, \mathrm{s}, \mathrm{CH}_{2}\right), 5.30\left(2 \mathrm{H}, \mathrm{s}, \mathrm{CH}_{2}\right), 7.20-7.36(4 \mathrm{H}$, $\mathrm{m}, \mathrm{ArH})$.

\section{Synthesis of methyl-2-(2-(bromomethyl)phenyl)acetate (3)}

To a solution of compound (2) $(1 \mathrm{~g}, 6.75 \mathrm{mmol})$ in methanol $(0.9 \mathrm{~mL})$ and anhydrous toluene $(30 \mathrm{~mL})$, thionyl bromide $(0.71 \mathrm{~mL}, 9.18 \mathrm{mmol})$ was dropwise added. The reaction mixture was stirred at $90^{\circ} \mathrm{C}$ for $2 \mathrm{~h}$. After the reaction, the resulting mixture was poured into a saturated sodium carbonate solution and stirred for 10 mins. The organic and aqueous layer was extracted with water and dichloromethane, respectively. The combined organic extracts were dried with magnesium sulfate and then evaporated to dryness to give the product (3). Brown oil, yield: $50 \%,{ }^{1} \mathrm{H}$ NMR $\left(400 \mathrm{~Hz}, \mathrm{CDCl}_{3}\right)$ $\delta=3.73\left(3 \mathrm{H}, \mathrm{s}, \mathrm{OCH}_{3}\right), 3.83\left(2 \mathrm{H}, \mathrm{s}, \mathrm{CH}_{2}\right), 4.60(2 \mathrm{H}, \mathrm{s}$, $\left.\mathrm{CH}_{2}\right), 7.29-7.40(4 \mathrm{H}, \mathrm{m}, \mathrm{ArH})$.

\section{Synthesis of 2-chloro-nitro-4(p-tolyloxy)benzene (5)}

2,4-Dicholoronitrobenzene ( $1 \mathrm{~g}, 6.29 \mathrm{mmol})$, 4-methylphenol $(680 \mathrm{mg}, 6.29 \mathrm{mmol})$ and potassium carbonate $(869 \mathrm{mg}$, $6.29 \mathrm{mmol}$ ) were dissolved in anhydrous acetonitrile $(30 \mathrm{~mL})$ and refluxed for $15 \mathrm{~h}$. After the reaction, the solvent was removed under vacco, and the resultant 


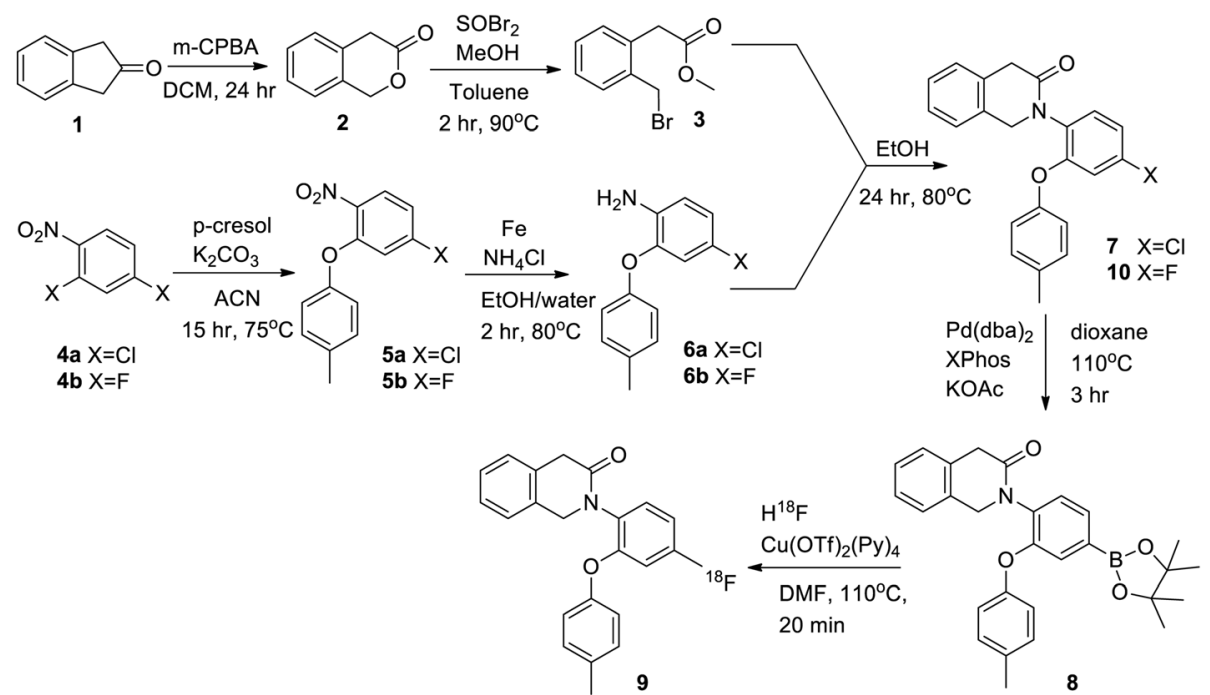

Fig. 1 The synthetic scheme of the precursor for radiofluorination $(\mathbf{8}),\left[^{18} \mathrm{~F}\right] \mathrm{FTPQ}(\mathbf{8})$, and authentic standard (10)

was dissolved in ethyl acetate and then extracted with sodium hydroxide solution $(1 \mathrm{~N})$. The organic layer was collected and dried with magnesium sulfate to afford a crude product, which was then purified by column chromatography (hexane $/ \mathrm{CH}_{2} \mathrm{Cl}_{2}=4 / 1$ ) to give the product (5). Yellow powder, yield: $64 \%,{ }^{1} \mathrm{H}$ NMR $\left(400 \mathrm{~Hz}, \mathrm{CDCl}_{3}\right)$ $\delta=2.39\left(3 \mathrm{H}, \mathrm{s}, \mathrm{CH}_{3}\right), 6.90(1 \mathrm{H}, \mathrm{d}, J=8.8 \mathrm{~Hz} \mathrm{ArH}), 6.97$ $(2 \mathrm{H}, \mathrm{d}, J=7.6 \mathrm{~Hz}, \mathrm{ArH}), 7.03(1 \mathrm{H}, \mathrm{s}, \mathrm{ArH}), 7.24(2 \mathrm{H}, \mathrm{d}, J=$ $7.6 \mathrm{~Hz}, \mathrm{ArH}), 7.96$ (1H, d, $J=7.6 \mathrm{~Hz}, \mathrm{ArH})$.

\section{Synthesis of 4-chloro-2-(p-tolyloxy)aniline (6)}

Compound (5) $(500 \mathrm{mg}, 1.9 \mathrm{mmol})$ was added into a solution of Fe powder (424 mg, $7.6 \mathrm{mmol}$ ) and ammonium chloride (51 $\mathrm{mg}, 0.95 \mathrm{mmol}$ ) in methanol a mixture of $\mathrm{EtOH} /$ water $(5 / 2,7 \mathrm{~mL})$. The reaction mixture was stirred at $80^{\circ} \mathrm{C}$ for $1.5 \mathrm{~h}$. After the reaction, the mixture was concentrated in vacco system. The residue was dissolved by ethyl acetate, and the mixture was extracted with brine. The organic extract was collected and dried by dried with magnesium sulfate to afford the product (6). Yellow oil, yield: $90 \%,{ }^{1} \mathrm{H}$ NMR $\left(400 \mathrm{~Hz}, \mathrm{CDCl}_{3}\right) \delta=$ $2.34\left(3 \mathrm{H}, \mathrm{s}, \mathrm{CH}_{3}\right), 6.7-6.98(5 \mathrm{H}, \mathrm{m}, \mathrm{ArH}), 6.79(1 \mathrm{H}, \mathrm{s}$, ArH), 7.15-7.16 (2H, d, ArH).

\section{Synthesis of 2-(4-chloro-2-(p-tolyloxy)phenyl)-1,2- dihydroisoquinolin-3(4H)-one (7)}

Compound (3) (500 mg, $2.057 \mathrm{mmol}$ ) and compound (6) (721 mg, $3.085 \mathrm{mmol}$ ) were dissolved in ethanol $(6 \mathrm{~mL})$. The reaction mixture was reacted at $80^{\circ} \mathrm{C}$ for $1 \mathrm{~d}$. After the reaction, the mixture was evaporated in vacco system to dryness, and the crude residue was purified by column chromatography $\left(\mathrm{CH}_{2} \mathrm{Cl}_{2} / \mathrm{EA}=10 / 1\right)$ to afford the product (7). Yellow solid, yield: $76 \%,{ }^{1} \mathrm{H}$ NMR (400 $\left.\mathrm{Hz}, \mathrm{CDCl}_{3}\right) \delta=2.30\left(3 \mathrm{H}, \mathrm{s}, \mathrm{CH}_{3}\right), 3.67\left(2 \mathrm{H}, \mathrm{s}, \mathrm{CH}_{2}\right), 4.74$
(2H, s, $\left.\mathrm{CH}_{2}\right), 6.88-7.11(3 \mathrm{H}, \mathrm{m}, \mathrm{ArH}), 7.12-7.27(8 \mathrm{H}, \mathrm{m}$, ArH). ${ }^{13} \mathrm{C}$ NMR $\left(400 \mathrm{~Hz}, \mathrm{CDCl}_{3}\right) \quad \delta=20.7,38.2,53.7$, 119.0, 119.5, 123.7, 125.1, 126.7, 127.3, 127.7, 130.3, 130.4, 131.2, 131.8, 132.4, 133.9, 134.1, 153.6, 153.9, 169.4 .

\section{Synthesis of 2-(4-(4,4,5,5-tetramethyl-1,3,2-dioxaborolan-2-} yl)-2-(p-tolyloxy)phenyl)-1,2-dihydroisoquinolin-3(4H)-one (8) Compound (7) (1 g, $2.75 \mathrm{mmol})$, bis(pinacolato)diboron $(2.09 \mathrm{~g}, 8.25 \mathrm{mmol})$, potassium acetate $(810 \mathrm{mg}$, $8.25 \mathrm{mmol}), \mathrm{Pd}(\mathrm{dba})_{2}(0)(31.6 \mathrm{mg}, 0.06 \mathrm{mmol})$, and 2-dicyclohexylphosphino-2',4',6' -triisopropylbiphenyl $(52.5 \mathrm{mg}$, $0.11 \mathrm{mmol}$ ) were dissolved in dioxane $(5 \mathrm{~mL})$. The mixture was reacted at $110^{\circ} \mathrm{C}$ for $3 \mathrm{~h}$. After the reaction, the reaction mixture was concentrated in vacco to remove the solvent. The residue was dissolved in dichloromethane and extracted with brine. The organic layer was collected and dried with magnesium sulfate to afford a crude product, which was then purified by column chromatography $\left(\mathrm{CH}_{2} \mathrm{CH}_{2} / \mathrm{EA}=5 / 1\right)$. The product $(8)$ was washed with hexane and then recrystallized in a hexane/dichloromethane system. White solid, yield: $73 \%,{ }^{1} \mathrm{H}$ NMR $(400 \mathrm{~Hz}$, $\left.\mathrm{CDCl}_{3}\right) \delta=1.28\left(12 \mathrm{H}, \mathrm{s}, \mathrm{CH}_{3}\right), 2.24\left(3 \mathrm{H}, \mathrm{s}, \mathrm{CH}_{3}\right), 3.58$ $\left(2 \mathrm{H}, \mathrm{s}, \mathrm{CH}_{2}\right), 4.68\left(2 \mathrm{H}, \mathrm{s}, \mathrm{CH}_{2}\right), 6.80(2 \mathrm{H}, \mathrm{d}, J=7.6 \mathrm{~Hz}$, $\mathrm{ArH}), 7.0(2 \mathrm{H}, \mathrm{d}, J=8.0 \mathrm{~Hz} \mathrm{ArH}) .7 .07-7.23(4 \mathrm{H}, \mathrm{m}, \mathrm{ArH})$, $7.30(1 \mathrm{H}, \mathrm{d}, J=7.6 \mathrm{~Hz}, \operatorname{ArH}), 7.47(1 \mathrm{H}, \mathrm{s}, \operatorname{ArH}), 7.61(1 \mathrm{H}$, d, $J=7.6 \mathrm{~Hz} \mathrm{ArH}){ }^{13} \mathrm{C}$ NMR $\left(400 \mathrm{~Hz}, \mathrm{CDCl}_{3}\right) \delta=20.6$, $24.8,38.3,53.6,84.0,117.6,125.1,126.6,126.9,127.2$, $127.6,129.0,130.0,130.8,132.1,132.4,132.5,136.2$, 151.8, 155.0, 169.2. LRMS (ES+): $\mathrm{m} / \mathrm{z}$ calculated for $\mathrm{C}_{22} \mathrm{H}_{19} \mathrm{O}_{2} \mathrm{NF}: 348.1389$.

\section{Synthesis of the authantic standard (10)}

Compound (10) was prepared according to the method described above, except for 2,4-dicholoronitrobenzene 
was replaced by 2,4-difluoronitrobenzene. Yellow solid, yield: $73 \%,{ }^{1} \mathrm{H}$ NMR $\left(400 \mathrm{~Hz}, \mathrm{CDCl}_{3}\right) \delta=2.31(3 \mathrm{H}, \mathrm{s}$, $\left.\mathrm{CH}_{3}\right), 3.69\left(2 \mathrm{H}, \mathrm{s}, \mathrm{CH}_{2}\right), 4.76\left(2 \mathrm{H}, \mathrm{s}, \mathrm{CH}_{2}\right), 6.65(1 \mathrm{H}, \mathrm{d}$, $J=10 \mathrm{~Hz}, \mathrm{ArH}), 6.82(1 \mathrm{H}, \mathrm{t}, J=10 \mathrm{~Hz}, \mathrm{ArH}), 6.91(2 \mathrm{H}, \mathrm{d}$, $J=7.6 \mathrm{~Hz}, \mathrm{ArH}), 6.82(2 \mathrm{H}, \mathrm{d}, J=8 \mathrm{~Hz}, \mathrm{ArH}), 7.14(1 \mathrm{H}, \mathrm{d}$, $J=7.2 \mathrm{~Hz}, \mathrm{ArH}), 7.19(1 \mathrm{H}, \mathrm{d}, J=7.2 \mathrm{~Hz}, \mathrm{ArH}), 7.24-7.28$ $(3 \mathrm{H}, \mathrm{m}, \mathrm{ArH}) .{ }^{13} \mathrm{C}$ NMR $\left(400 \mathrm{~Hz}, \mathrm{CDCl}_{3}\right) \delta=20.7,38.2$, 53.9, 106.6, 106.8, 110.2, 110.4, 119.1, 125.1, 126.7, $127.3,127.7,130.4,130.5,131.9,132.4,133.9,153,6$, $154.5,154.6,160.1,163.5,169.5$. HRMS (ES+): $\mathrm{m} / \mathrm{z}$ calculated for $\mathrm{C}_{22} \mathrm{H}_{19} \mathrm{O}_{2} \mathrm{NF}$ : 348.1389 .

\section{Preparation of $\left[{ }^{18} \mathrm{~F}\right] \mathrm{FTPQ}$}

Aqueous no-carrier-added $\left[{ }^{18} \mathrm{~F}\right] \mathrm{HF}$ was transferred through a QMA Sep-Pak cartridge conditioned with ethanol $(10 \mathrm{~mL})$, KOTf solution $(90 \mathrm{mg} / \mathrm{mL}, 10 \mathrm{~mL})$, and $\mathrm{dd}_{2} \mathrm{O}(10 \mathrm{~mL})$. The fluoride trapped in QMA cartridge was eluted with $0.55 \mathrm{~mL}$ of eluent $(100 \mathrm{mg}$ of KTOf and $1 \mathrm{mg}$ of $\mathrm{K}_{2} \mathrm{CO}_{3}$ in $11 \mathrm{~mL}$ of $\mathrm{ddH}_{2} \mathrm{O}$ ) to a $\mathrm{V}$-vial. The solvent was evaporated to dryness at $110^{\circ} \mathrm{C}$, and then anhydrous acetonitrile $(1 \mathrm{~mL})$ was added into the vial as an azeotrope. To the dry residue, $3 \mathrm{mg}$ of precursor $(8)$ and $0.5 \mathrm{~mL}$ of catalyst solution $\left(\mathrm{Cu}(\mathrm{II})(\mathrm{OTf})_{2}\right.$-Pyridine DMF, $36.5 \mathrm{mg}$ of $\mathrm{Cu}(\mathrm{OTf})_{2}$ dissolved in $0.2 \mathrm{~mL}$ of pyridine and $2.5 \mathrm{~mL}$ of DMF) were added. The reaction mixture was reacted at $110^{\circ} \mathrm{C}$ for $20 \mathrm{~min}$. After cooling, the reaction mixture was passed through a Plus Silica SepPak cartridge (Waters, USA), which was preconditioned with $10 \mathrm{~mL}$ hexane. The crude product trapped in SepPak was eluted with $2 \mathrm{~mL}$ of dichloromethane. After evaporation of the solvent under a stream of nitrogen at $110^{\circ} \mathrm{C}$, the mixture was re-dissolved in acetonitrile. The collected crude product was purified by high-performance liquid chromatography (HPLC), which was performed on a reversed-phase column (semipreparative (VP 250/10) NUCLEODUR C18 HTEC, $5 \mu \mathrm{m}$ ) using $70 \%$ acetonitrile in $\mathrm{ddH}_{2} \mathrm{O}$ as the mobile phase at a flow rate of $4 \mathrm{~mL} / \mathrm{min}$. The desired fraction was collected and then evaporated to dryness for removing acetonitrile. The residue was redissolved with normal saline and then filtered by a $0.22-\mu \mathrm{m}$ filter (Millex-OR, Millipore). The specific activity of $\left[{ }^{18} \mathrm{~F}\right] \mathrm{FTPQ}$ was determined using an analytical C-18 HPLC column (NUCLEODUR C18 HTEC, $5 \mu \mathrm{m}$ ) eluted with 70\% acetonitrile in $\mathrm{ddH}_{2} \mathrm{O}$ at a flow rate of $1 \mathrm{~mL} / \mathrm{min}$.

\section{Partition coefficient of $\left[{ }^{18} \mathrm{~F}\right] \mathrm{FTPQ}$}

The partition coefficient of $\left[{ }^{18} \mathrm{~F}\right] \mathrm{FTPQ}$ was assessed by determining its distribution between 1-octane and phosphate buffer saline (PBS) and expressed as $\log P$. To a tube containing $1 \mathrm{~mL}$ of 1 -octane and $1 \mathrm{~mL}$ of PBS, $\left[{ }^{18} \mathrm{~F}\right] \mathrm{FTPQ}(7.4 \mathrm{kBq})$ was added then the mixture was vortexed for $1 \mathrm{~min}$. After vortexing, the tube was centrifuged at $1000 \mathrm{~g}$ for $5 \mathrm{~min}$. Aliquots $(500 \mu \mathrm{L})$ were taken from the organic phase and added into the next tube.
These steps were repeated for five times. Finally, a hundred microliters of each layer were collected for the measurement of radioactivity by a gamma counter (1470 WIZARD Gamma Counter, Wallac, Finland).

\section{Stability of $\left[{ }^{18} \mathrm{~F}\right] \mathrm{FTPQ}$}

$\left[{ }^{18} \mathrm{~F}\right] \mathrm{FTPQ}$ was incubated in either normal saline or fetal bovine serum (FBS) at $37^{\circ} \mathrm{C}$ for $30,60,120$, and $240 \mathrm{~min}$ to investigate the in vitro stability, which expressed as the percentage of the intact radioactive compound analyzed by radioTLC.

\section{Establishment of 6-OHDA-lesioned animal model}

The protocol was based on the method published by Weng et al. with some minor modifications [17]. Briefly, male 8-week-old Sprague-Dawley rats, purchased from LASCO Taiwan Co., Ltd. (Yilan, Taiwan), were placed in a stereotaxic device and anesthetized under $2 \%$ isoflurane in $\mathrm{O}_{2}$. When the heart rate of rats reached a steady state, a small hole located on the right side of the skull $(1.2 \mathrm{~mm}$ right lateral to and $4.4 \mathrm{~mm}$ posterior to the bregma) was created by an electric drill for animal use. Twenty micrograms of 6-hydroxydopamine (6-OHDA, in $4 \mu \mathrm{L}$ of normal saline containing $0.02 \%$ ascorbic acid) were injected into the brain using syringe pump $(1 \mu \mathrm{L} / \mathrm{min})$ on day 0 . The injection point was $7.8 \mathrm{~mm}$ below the dura. After injection, the syringe was vertically kept for $5 \mathrm{~min}$, and slowly removed from the brain at a rate of $1 \mathrm{~mm} / \mathrm{min}$. The hole was covered with a bone flap, and the wound was sealed after administration. The rats in the sham group received the same procedures except for the 6-OHDA injection $(n=5)$.

\section{Apomorphine-induced rotational behavior test}

For a selection of diseased rats, the rats were intraperitoneally injected with apomorphine $(5 \mathrm{mg} / \mathrm{kg})$ on day 14 after 6-OHDA administration. The rats were then subjected to a rotational behavior test for at least $100 \mathrm{~min}$. Only those with contralateral rotation $>300$ turns $/ \mathrm{h}$ were used in following imaging experiments $(n=5)$.

\section{$\left[{ }^{18} \mathrm{~F}\right] \mathrm{FTPQ}$ microPET imaging}

Imaging studies were performed on a microPET scaaner (Inveon PET, Siemens). Static microPET/CT imaging was conducted for $30 \mathrm{~min}$ immediately after injection of $18.5 \mathrm{MBq}$ of $\left[{ }^{18} \mathrm{~F}\right] \mathrm{FTPQ}$ on days 7,14 and 21 for diseased animals and controls $(n \geqq 5)$. During the examination, the rats were anesthetized with $2 \%$ isoflurane in $\mathrm{O}_{2}$ and placed in the prone position with the long axis parallel to the table of the scanner. The rats were sacrificed by $\mathrm{CO}_{2}$ inhalation immediately after imaging studies for histological analysis to confirm the biological features of PD. 


\section{Histological analysis}

After microPET/CT imaging, the PD rats were sacrificed and perfused with $100 \mathrm{~mL}$ of phosphate buffer solution. The brains were excised for immunohistochemistry staining to assess the expression levels of the dopaminergic pathway, and the number of microglia and astrocytes. The dehydration, paraffin embedding, and section steps were conducted as previously described [18]. The slices were incubated with $3 \%$ $\mathrm{H}_{2} \mathrm{O}_{2}$ for 20 min and then blocked with Protein Block (Abcam) at r.t. for $10 \mathrm{~min}$. Heat-induced antigen retrieval was performed with $0.01 \mathrm{M}$ of citrate buffer $(\mathrm{pH}=6.0)$ at $85^{\circ} \mathrm{C}$ for $30 \mathrm{~min}$. The rat monoclonal antibodies against tyrosine hydroxylase $(\mathrm{TH}$, ab112, Abcam), CD68 (mca341r, Bio-Rad), and GFAP (Z0334, Dako) were applied to the slides at a dilution of 1:750, 1:100, and 1:1000, respectively. The slides for $\mathrm{TH}$, CD68, and GFAP staining were exposed to the rabbit specific HRP/DAB detection kit (ab64261, Abcam for TH; S8125, Dako for CD68; SK4600, Vector for GFAP) until the brown or purple stains were observed.

\section{Statistical analysis}

All data were expressed as the mean \pm standard deviation (S.D.). The Student's $t$-tests were applied for the comparison between groups. Values of $P<0.05$ were considered as statistically significant.

\section{Results}

The synthesis of the precursor (8) and authentic standard (10) After multi-step synthesis, the overall chemical yield for the precursor $(8)$ and authentic standard (10) was 14 and $6 \%$, respectively. The ${ }^{1} \mathrm{H},{ }^{13} \mathrm{C}$ NMR, and mass spectrometry for all compounds were shown in the Additional file 1.

\section{Preparation of $\left[{ }^{18} \mathrm{~F}\right] \mathrm{FTPQ}$}

The radiofluorination efficiency of $\left[{ }^{18} \mathrm{~F}\right] \mathrm{FTPQ}$ was around $60 \pm 5 \%$ (Fig. 2a). After the purification using Sep-Pak cartridge, most of the unlabeled radiofluorine would be removed (Fig. 2b). Increasing reaction time (more than 20 $\mathrm{min}$ ) did not facilitate the SN2 reactivity to give higher labeling efficiency (data not shown). After HPLC separation, the radiochemical purity of the desired product was greater than $98 \%$. The retention time of authentic standard and $\left[{ }^{18} \mathrm{~F}\right] \mathrm{FTPQ}$ was 9.227 and $9.390 \mathrm{~min}$, respectively (Fig. 2c). A small difference in the retention time between standard and radioactive ligand originated from the travel time in the connecting loop and suggested radioactive ligand owns the identical structure with that of standard. The total preparation time for $\left[{ }^{18} \mathrm{~F}\right] \mathrm{FTPQ}$ was approximately $100 \mathrm{~min}$ with an overall radiochemical yield of $19 \%$, which was corrected for the physical decay (d.c.).
The specific activity of $\left[{ }^{18} \mathrm{~F}\right] \mathrm{FTPQ}$, determined by analytic HPLC column, was approximately $1.5 \mathrm{GBq} / \mu \mathrm{mol}$.

\section{In vitro stability and partition coefficient of $\left[{ }^{18} \mathrm{~F}\right] \mathrm{FTPQ}$} The in vitro stability of $\left[{ }^{18} \mathrm{~F}\right] \mathrm{FTPQ}$ in either normal saline or FBS at $37^{\circ} \mathrm{C}$ was assessed by a radioTLC scanner. The percentage of intact $\left[{ }^{18} \mathrm{~F}\right] \mathrm{FTPQ}$ was more than $90 \%$ in both conditions after $4 \mathrm{~h}$ of incubation (Fig. 3). A log $P$ value of $1.69 \pm 0.16$ in $\mathrm{n}$-octanol/water revealed that $\left[{ }^{18}\right.$ F]FTPQ is considerably a hydrophobic compound, which may enhance its penetration through the bloodbrain barrier (BBB).

\section{MicroPET/CT imaging}

The microPET/CT images demonstrated apparent striatum accumulation in the brains of PD rats $(n=5)$ at the first $30 \mathrm{~min}$ after intravenous injection of $\left[{ }^{18} \mathrm{~F}\right] \mathrm{FTPQ}$, while the uptake in the sham group $(n=5)$ was not evident (Fig. 4). Longitudinal imaging found the uptake of $\left[{ }^{18}\right.$ F]FTPQ in the brain may reflect the severity of PD. The radioactivity accumulated in the ipsilateral brains of PD rats at 1,2 , and 3 weeks after 6-OHDA administration was $1.84 \pm 0.26,3.43 \pm 0.45$, and $5.58 \pm 0.72 \% \mathrm{ID} / \mathrm{mL}$, respectively. However, the clearance of $\left[{ }^{18} \mathrm{~F}\right] \mathrm{FTPQ}$ from the brains of the sham group was more rapid than that of the PD rats, resulting in a relatively low uptake in the brain $(1.57 \pm 0.29 \% \mathrm{ID} / \mathrm{mL})$. The ipsilateral semisphereto-cerebellum ratio derived from the $\left[{ }^{18} \mathrm{~F}\right] \mathrm{FTPQ}$ mircroPET/CT images of the 1-, 2-, 3-week PD and the control groups was $1.51 \pm 0.39,2.51 \pm 0.40, \quad 3.90 \pm 0.67$, and $1.13 \pm 0.26$, respectively.

\section{Histological analysis}

Tyrosine hydroxylase (TH) staining was applied to confirm the loss of dopamine neurons in the striatum and substantia nigra of PD rats. In rats received 6-OHDA, the $\mathrm{TH}$ stains markedly decreased when compared with that of the sham group (Fig. 5a), suggesting 6-OHDA-treated rats are appropriately considered as those mimicking the pathology in the patients with PD. When compared with the contralateral hemisphere, the 6-OHDA-injected side showed intense CD68 and GFAP staining (Fig. 5b and c), which are considered as markers for pan-macrophage and microglia, and reactive astrocytes index, respectively, suggesting the high accumulation of $\left[{ }^{18} \mathrm{~F}\right] \mathrm{FTPQ}$ was associated with neuroinflammation in the brains of PD rats.

\section{Discussion}

The 4-chlorodiazepam (Ro5-4864) exhibits nanomolar affinity to TSPO as well as PK11195 in some species [19]. Elakamhawy et al. developed the derivatives of Ro5-4864 via opening its diazepine ring and found some of these compounds are capable of modulating MPTP at nanomolar range [16], suggesting their strong binding 
(a)

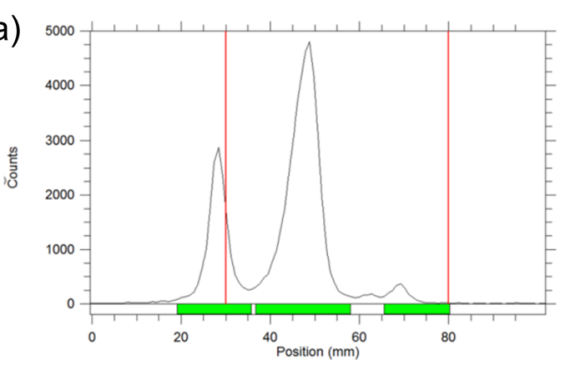

(b)

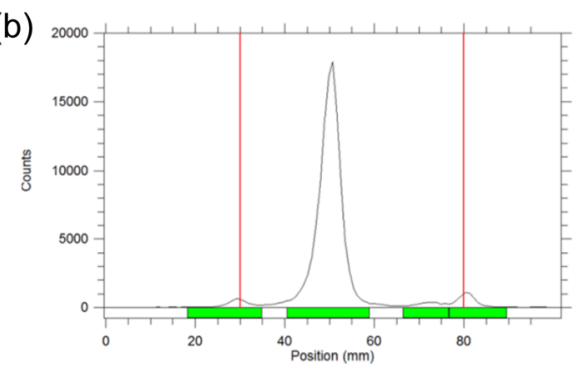

(c)
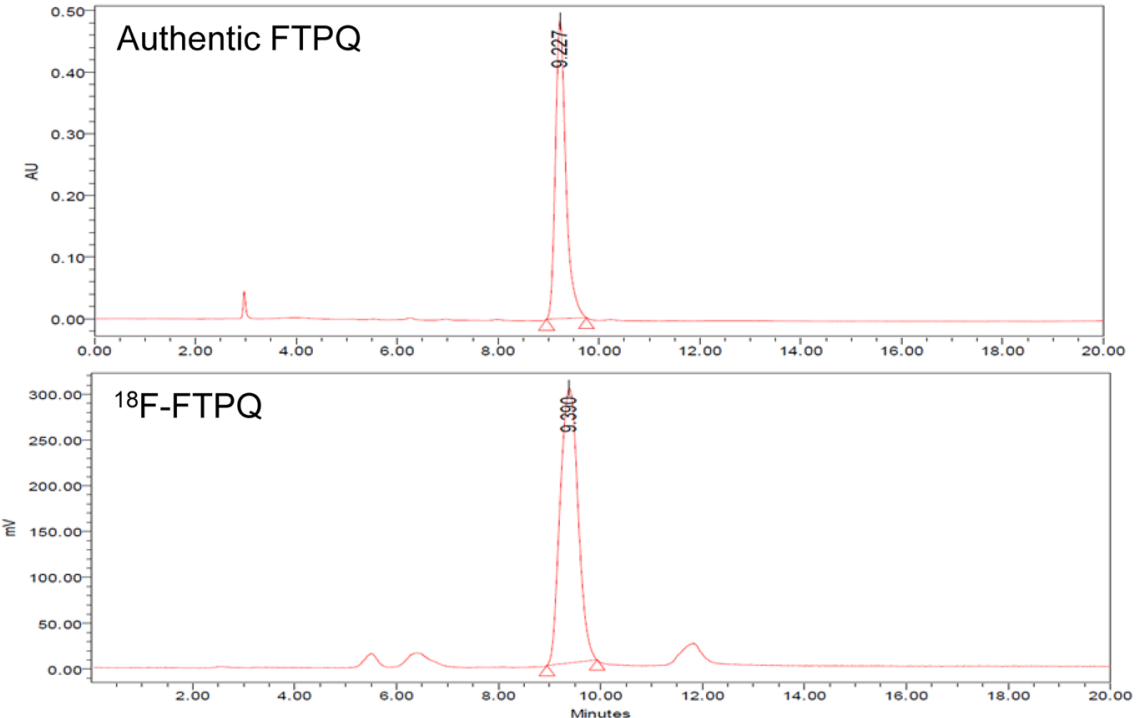

Fig. 2 RadioTLC of crude $\left[{ }^{18} \mathrm{~F}\right] \mathrm{FTPQ}$ (a) before and (b) after the Sep-pak cartridge purification. c HPLC of $\left[{ }^{18} \mathrm{~F}\right] \mathrm{FTPQ}$. The retention time of authentic FTPQ and $\left[{ }^{18} \mathrm{~F}\right] \mathrm{FTPQ}$ was 9.23 and 9.39 min, respectively

affinity to TSPO. Considering no previous study investigated the in vivo distribution of this class of compounds, this study was designed to explore the biological characteristics of a new TSPO ligand, $\left[{ }^{18} \mathrm{~F}\right] \mathrm{FTPQ}$. For the synthesis of the precursor $(\boldsymbol{8})$ for radiolabeling, the addition of boron ester on the compound (7) is the most critical step. In fact, this reaction would not work if $\left[1,1^{\prime}\right.$-Bis(diphenylphosphino)ferrocene]dichloropalladium (II) (complex with dichloromethane, $\mathrm{Pd}(\mathrm{dppf}) \mathrm{Cl}_{2} \cdot \mathrm{DCM}$ ) was used as a catalyst, suggesting the electron density of the

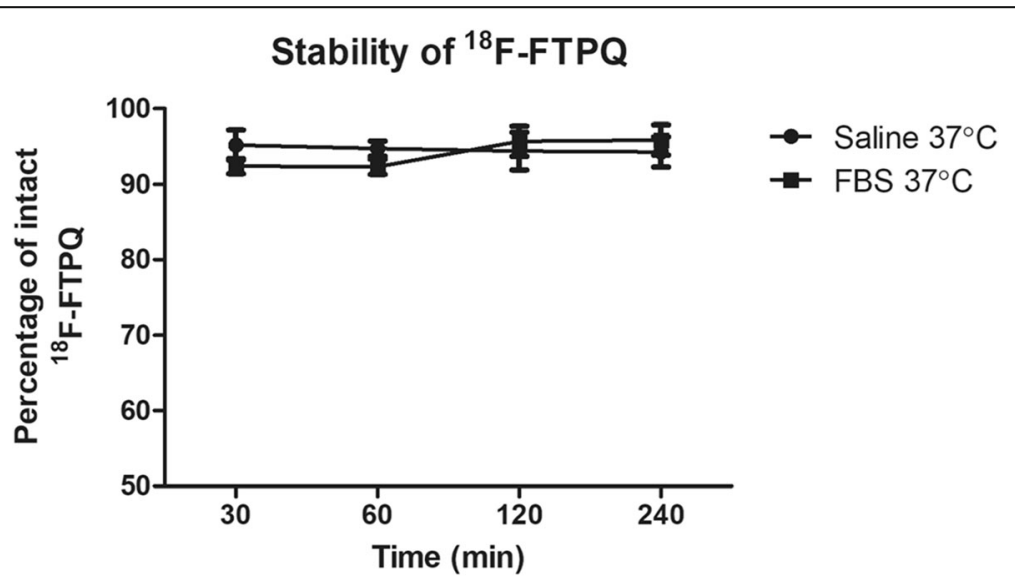

Fig. 3 In vitro stability of $\left[{ }^{18} \mathrm{~F}\right] \mathrm{FTPQ}$ in either normal saline or in $\mathrm{FBS}$ at $37^{\circ} \mathrm{C}$ 


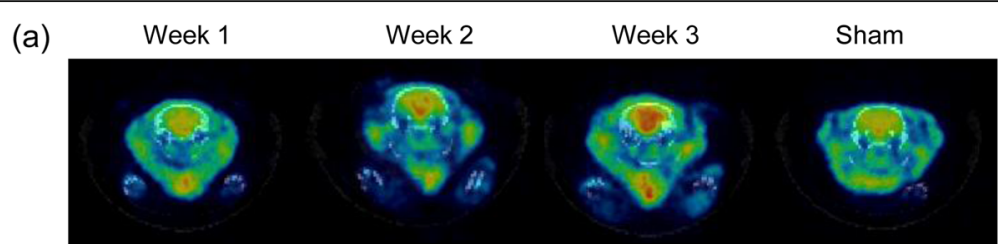

(b)

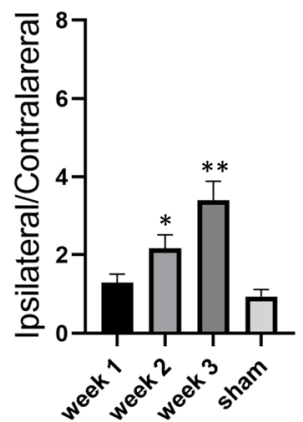

(c)

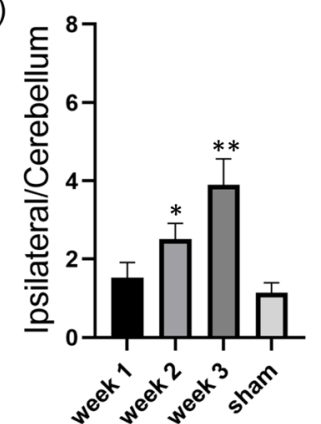

Fig. 4 a MicroPET/CT imaging of PD rats after intravenous injection of approximately $18.5 \mathrm{MBq}$ of $\left[{ }^{18} \mathrm{~F}\right] \mathrm{FTPQ}$ for $30 \mathrm{~min}$. The semi-quantitative analysis of (b) ipsilateral hemisphere-to-contralateral hemisphere ratio and (c) ipsilateral hemisphere-to-cerebellum ratio from the images of the 1-, 2-, and 3-week old PD rats and the sham rats. *significant where $P<0.05,{ }^{* *}$ where significant where $P<0.001$ (PD diseased rats compared with sham groups)

catalyst apparently affects the catalytic activity. For radiolabeling, the reason for the relatively low radiochemical yield actually originated from the poor solubility of $\left[{ }^{18} \mathrm{~F}\right] \mathrm{FTPQ}$.

It is suggested that the inflammatory processes of $\mathrm{PD}$ vary over time. Therefore, optimal management could benefit from a reliable noninvasive imaging technique that can reflect disease progression or severity. The 6OHDA-lesioned rat model is regarded as an appropriate animal model for preclinical studies. Maia et al. discovered that the in vitro accumulation of $\left[{ }^{3} \mathrm{H}\right] \mathrm{PK} 11195$ in the ipsilateral striatum on day 21 post-lesion (p.l.) was significantly lower than that on day 7 p.l. [20]. The ex

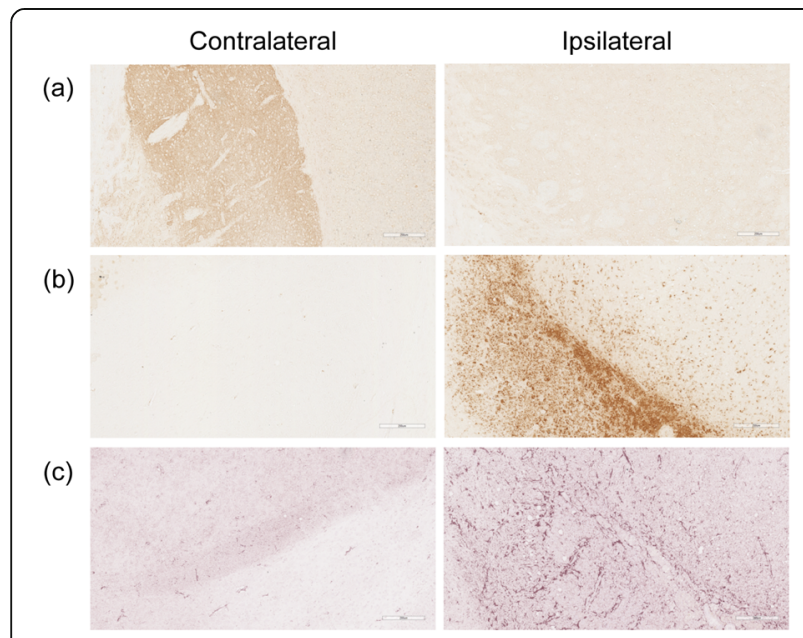

Fig. 5 Immunohistochemical staining of the brain sections from PD rats and the controls. The brain was excised from rats to assess the difference in (a) tyrosine hydroxylase (TH) expression, (b)

macrophage activation (CD68), and (c) astrocyte activation (GFAP) vivo binding of ${ }^{125}$ I-CLINDE to the ipsilateral striatum was similar on days 7 and day 14 p.l. but decreased apparently on day 21 p.l. [20]. Vetel et al. also found the specific retention of $\left[{ }^{3} \mathrm{H}\right] \mathrm{DPA}-714$ in the ipsilateral striatum was significantly higher than that in the contralateral striatum on day 14 p.l. [21]. Besides, previous clinical PET imaging using $\left[{ }^{11} \mathrm{C}\right]$ PK11195 revealed a high uptake in the brain of PD patients due to the activated microglia $[11,12]$. However, this finding was not conclusive since some groups reported dramatically different results that did not observe significant radioactivity retained in the PD brains [13]. Terada et al. demonstrated similar elevated TSPO binding in the PD patients' brains when using $\left[{ }^{11} \mathrm{C}\right] \mathrm{DPA}-713$ as a radioligand for the assessment [22], but not in the investigations using $\left[{ }^{18} \mathrm{~F}\right]$ FEPPA performed by Koshimori et al. [23] and Ghadery et al. [24].

The imaging results of $\left[{ }^{18} \mathrm{~F}\right] \mathrm{FTPQ}$ in this study corroborate previous findings with $\left[{ }^{11} \mathrm{C}\right] \mathrm{PK} 11195[11,12]$ and $\left[{ }^{11}\right.$ C]DPA-713 [22] showing enhanced brain accumulation in PD rats (Fig. 4). In addition, the uptake of $\left[{ }^{18} \mathrm{~F}\right] \mathrm{FTPQ}$ in PD brains increased over the experimental period, suggesting the radioactivity accumulation can be a quantification index for monitoring PD activity (Fig. 4) although the profile was inconsistent with the previous $\left[{ }^{11}\right.$ C]PK11195 autoradiography results, which demonstrated the maximum TSPO expression occurred on day 7 p.l. [20]. The possible explanations for this discrepancy are the difference in binding affinity between $\left[{ }^{18} \mathrm{~F}\right] \mathrm{FTPQ}$ and $\left[{ }^{11} \mathrm{C}\right] \mathrm{PK} 11195$, and the autoradiography findings were obtained from in vitro experiments rather than from in vivo. In fact, the lower $\log P$ value of $\left[{ }^{18} \mathrm{~F}\right] \mathrm{FTPQ}$ than that of PK11195 can account for its reduced nonspecific binding in the brain of the sham group (Fig. 4). 
Similar to previous studies [25, 26], immunohistochemical staining for CD68 and GFAP revealed that brains from 6-OHDA-lesioned PD rats have a significantly increased number of microglia/macrophages and astrocytes compared to the contralateral sites (Fig. 5).

As mentioned above, $\left[{ }^{18} \mathrm{~F}\right] \mathrm{FTPQ}$ shares a similar scaffold with Ro5-4864, which binds to TSPO in a temperatureand species-dependent manner [27]. In addition, a singlenucleotide polymorphism, rs6917, has been confirmed as a critical factor affecting the binding affinity of second-generation TSPO radioligand and causing inter-individual variability [28]. Further experiments are warranted to clarify these issues.

\section{Conclusions}

In this study, we have successfully synthesized a new TSPO radioligand, $\left[{ }^{18} \mathrm{~F}\right] \mathrm{FTPQ}$, with acceptable radiochemical yield and demonstrated that the accumulation of $\left[{ }^{18} \mathrm{~F}\right] \mathrm{FTPQ}$ in brain may be a useful index for the detection of PD and monitoring the disease progression. To our best knowledge, this is the first study to determine the in vivo pharmacokinetics of this new class of TSPO ligand through noninvasive imaging technique.

\section{Additional file}

Additional file 1: All spectral data of compound 1-10. (DOCX $2913 \mathrm{~kb})$

\section{Abbreviations \\ $\left[{ }^{18} \mathrm{~F}\right] \mathrm{FTPQ}:\left[{ }^{18} \mathrm{~F}\right]-2$-(4-fluoro-2-(p-tolyloxy)phenyl)-1,2-dihydroisoquinolin-3(4H)- one; BBB: Brain-blood barrier; CNS: Central nervous system; FBS: Fetal bovine serum; HPLC: High-performance liquid chromatography; IHC: Immunohistochemistry; mPTP: Mitochondrial permeability transition pore; PBR: Peripheral benzodiazepine receptor; PBS: Phosphate buffer saline; PD: Parkinson's disease; PET: Positron emission tomography; TH: Tyrosine hydroxylase; TSPO: Translocator protein}

\section{Acknowledgments}

The authors thank the technical support from Medical Research Core Facility, Office of Research \& Development at China Medical University, Taiwan, and Center for Advanced Molecular Imaging and Translation, Chang Gung Memorial Hospital, Taiwan.

\section{Authors' contributions \\ This study was designed, directed and coordinated by CYW, TCH, and CHK. $\mathrm{TCH}$, and $\mathrm{CHK}$, as the principal investigators, provided conceptual and technical guidance for all aspects of the project. CYW and CYY planned and prepared the precursor and radiolabeled ligand. CYY and JJL performed animal studies including establishment of diseased animal model, microPET imaging, and analyzed the data with CYW. JPL and JKC designed the microPET imaging protocol. The manuscript was written by CYW and commented on by all authors. All authors read and approved the final version of the manuscript.}

\section{Funding}

This study was supported by the Ministry of Science and Technology, Taiwan (MOST 105-2623-E-039-001-NU), China Medical University, Taiwan (CMU104N-08, and CMU105-N-04), and China Medical University Hospital, Taiwan (CRS-108-026). These funding sources had no role in the design of this study and will not have any role during its execution, analyses, interpretation of the data, or decision to submit results.
Availability of data and materials

Data sharing is not applicable to this article as no datasets were generated or analysed during the current study.

\section{Ethics approval and consent to participate}

This article does not contain any studies with human participants performed by any of authors. All applicable international, national, and institutional guidelines for the care of animals were followed. The animal experimental pertocol was approved by the institutional animal care and use committee of the China Medical University, Taichung, Taiwan (protocol No: 2018-211).

\section{Consent for publication}

Not applicable

\section{Competing interests}

The authors declare that they have no competing interests.

\section{Author details}

${ }^{1}$ Department of Biomedical Imaging and Radiological Science, China Medical University, No.91, Hsueh-Shih Road, Taichung, Taiwan, 40402. ${ }^{2}$ Master Program for Biomedical Engineering, China Medical University, No.91, Hsueh-Shih Road, Taichung, Taiwan40402. ${ }^{3}$ Department of Biomedical Imaging and Radiological Sciences, National Yang-Ming University, No.155, Sec.2, Linong Street, Taipei, Taiwan11221. ${ }^{4}$ Institute of Biomedical Engineering and Nanomedicine, National Health Research Institutes, 35 Keyan Road, Zhunan, Miaoli County, Taiwan35053. ${ }^{5}$ Graduate Institute of Biomedical Sciences and School of Medicine, College of Medicine, China Medical University, No.91, Hsueh-Shih Road, Taichung, Taiwan, 40402.

${ }^{6}$ Department of Nuclear Medicine and PET Center, and Center of Augmented Intelligence in Healthcare, China Medical University Hospital, No. 2, Yude Road, North District, Taichung City, Taiwan40447. ${ }^{7}$ Department of Bioinformatics and Medical Engineering, Asia University, 500, Lioufeng Rd., Wufeng, Taichung, Taiwan41354.

Received: 25 June 2019 Accepted: 18 August 2019

Published online: 18 September 2019

\section{References}

1. Imamura K, Hishikawa N, Sawada M, Nagatsu T, Yoshida M, Hashizume Y. Distribution of major histocompatibility complex class II-positive microglia and cytokine profile of Parkinson's disease brains. Acta Neuropathol. 2003; 106(6):518-26.

2. McGeer PL, Itagaki S, Boyes BE, McGeer EG. Reactive microglia are positive for HLA-DR in the substantia nigra of Parkinson's and Alzheimer's disease brains. Neurology. 1988;38(8):1285-91.

3. Hirsch EC, Hunot S. Neuroinflammation in Parkinson's disease: a target for neuroprotection? Lancet Neurol. 2009;8(4):382-97.

4. Fu R, Shen Q, Xu P, Luo JJ, Tang Y. Phagocytosis of microglia in the central nervous system diseases. Mol Neurobiol. 2014;49(3):1422-34.

5. Guo Y, Kalathur RC, Liu Q, Kloss B, Bruni R, Ginter C, et al. Protein structure. Structure and activity of tryptophan-rich TSPO proteins. Science. 2015; 347(6221):551-5.

6. Liu GJ, Middleton RJ, Hatty CR, Kam WW, Chan R, Pham T, et al. The 18 kDa translocator protein, microglia and neuroinflammation. Brain Pathol. 2014; 24(6):631-53.

7. Streit WJ. Microglial response to brain injury: a brief synopsis. Toxicol Pathol. 2000:28(1):28-30

8. Bribes $E$, Bourrie $B$, Casellas P. Ligands of the peripheral benzodiazepine receptor have therapeutic effects in pneumopathies in vivo. Immunol Lett. 2003;88(3):241-7.

9. Ryu JK, Choi HB, McLarnon JG. Peripheral benzodiazepine receptor ligand PK11195 reduces microglial activation and neuronal death in quinolinic acid-injected rat striatum. Neurobiol Dis. 2005;20(2):550-61.

10. Torres SR, Frode TS, Nardi GM, Vita N, Reeb R, Ferrara P, et al. Antiinflammatory effects of peripheral benzodiazepine receptor ligands in two mouse models of inflammation. Eur J Pharmacol. 2000:408(2):199-211.

11. Edison P, Ahmed I, Fan Z, Hinz R, Gelosa G, Ray Chaudhuri K, et al. Microglia, amyloid, and glucose metabolism in Parkinson's disease with and without dementia. Neuropsychopharmacology. 2013;38(6):938-49. 
12. Gerhard A, Pavese N, Hotton G, Turkheimer F, Es M, Hammers A, et al. In vivo imaging of microglial activation with [11C](R)-PK11195 PET in idiopathic Parkinson's disease. Neurobiol Dis. 2006;21(2):404-12.

13. Bartels AL, Willemsen AT, Doorduin J, de Vries EF, Dierckx RA, Leenders KL. [11C]-PK11195 PET: quantification of neuroinflammation and a monitor of anti-inflammatory treatment in Parkinson's disease? Parkinsonism Relat Disord. 2010;16(1):57-9.

14. Alam MM, Lee J, Lee SY. Recent Progress in the development of TSPO PET ligands for Neuroinflammation imaging in neurological diseases. Nucl Med Mol Imaging. 2017;51(4):283-96.

15. Varnas K, Cselenyi Z, Jucaite A, Halldin C, Svenningsson P, Farde L, et al. PET imaging of [(11)C]PBR28 in Parkinson's disease patients does not indicate increased binding to TSPO despite reduced dopamine transporter binding. Eur J Nucl Med Mol Imaging. 2019;46(2):367-75.

16. Elkamhawy A, Park JE, Hassan AHE, Pae AN, Lee J, Park BG, et al. Design, synthesis, biological evaluation and molecular modelling of 2-(2aryloxyphenyl)-1,4-dihydroisoquinolin-3(2H)-ones: a novel class of TSPO ligands modulating amyloid-beta-induced mPTP opening. Eur J Pharm Sci. 2017; 104:366-81.

17. Zhou FC, Chiang YH, Wang Y. Constructing a new nigrostriatal pathway in the parkinsonian model with bridged neural transplantation in substantia nigra. J Neurosci. 1996;16(21):6965-74.

18. Tournier I, Bernuau D, Poliard A, Schoevaert D, Feldmann G. Detection of albumin mRNAs in rat liver by in situ hybridization: usefulness of paraffin embedding and comparison of various fixation procedures. J Histochem Cytochem. 1987:35(4):453-9.

19. Scarf AM, Luus C, Da Pozzo E, Selleri S, Guarino C, Martini C, et al. Evidence for complex binding profiles and species differences at the translocator protein (TSPO) (18 kDa). Curr Mol Med. 2012;12(4):488-93.

20. Maia S, Arlicot N, Vierron E, Bodard S, Vergote J, Guilloteau D, et al. Longitudinal and parallel monitoring of neuroinflammation and neurodegeneration in a 6-hydroxydopamine rat model of Parkinson's disease. Synapse. 2012;66(7):573-83.

21. Vetel S, Serriere S, Vercouillie J, Vergote J, Chicheri G, Deloye JB, et al. Extensive exploration of a novel rat model of Parkinson's disease using partial 6-hydroxydopamine lesion of dopaminergic neurons suggests new therapeutic approaches. Synapse. 2019;73(3)::22077.

22. Terada T, Yokokura M, Yoshikawa E, Futatsubashi M, Kono S, Konishi T, et al. Extrastriatal spreading of microglial activation in Parkinson's disease: a positron emission tomography study. Ann Nucl Med. 2016;30(8):579-87.

23. Koshimori Y, Ko JH, Mizrahi R, Rusjan P, Mabrouk R, Jacobs MF, et al. Imaging striatal microglial activation in patients with Parkinson's disease. PLoS One. 2015;10(9):e0138721.

24. Ghadery C, Koshimori Y, Coakeley S, Harris M, Rusjan P, Kim J, et al. Microglial activation in Parkinson's disease using [(18)F]-FEPPA. J Neuroinflammation. 2017;14(1):8.

25. Israel I, Ohsiek A, Al-Momani E, Albert-Weissenberger C, Stetter C, Mencl S, et al. Combined [(18)F]DPA-714 micro-positron emission tomography and autoradiography imaging of microglia activation after closed head injury in mice. J Neuroinflammation. 2016;13(1):140.

26. Wang Y, Yue X, Kiesewetter DO, Niu G, Teng G, Chen X. PET imaging of neuroinflammation in a rat traumatic brain injury model with radiolabeled TSPO ligand DPA-714. Eur J Nucl Med Mol Imaging. 2014;41(7):1440-9.

27. Awad M, Gavish M. Binding of [3H]Ro 5-4864 and [3H]PK 11195 to cerebral cortex and peripheral tissues of various species: species differences and heterogeneity in peripheral benzodiazepine binding sites. J Neurochem. 1987:49(5):1407-14.

28. Owen DR, Yeo AJ, Gunn RN, Song K, Wadsworth G, Lewis A, et al. An 18$\mathrm{kDa}$ translocator protein (TSPO) polymorphism explains differences in binding affinity of the PET radioligand PBR28. J Cereb Blood Flow Metab. 2012;32(1):1-5

\section{Publisher's Note}

Springer Nature remains neutral with regard to jurisdictional claims in published maps and institutional affiliations.

\section{Ready to submit your research? Choose BMC and benefit from:}

- fast, convenient online submission

- thorough peer review by experienced researchers in your field

- rapid publication on acceptance

- support for research data, including large and complex data types

- gold Open Access which fosters wider collaboration and increased citations

- maximum visibility for your research: over $100 \mathrm{M}$ website views per year

At BMC, research is always in progress.

Learn more biomedcentral.com/submissions 